\title{
A Linguistic Landscape Study of English in Yogyakarta: Its Representation of Power in Commercial Boards
}

\author{
Dewianti Khazanah $^{1}$, Hadi Sampurna ${ }^{2}$, Reni Kusumaningputri ${ }^{3}$, Riskia Setiarini ${ }^{4}$, and \\ Supiastutik $^{5}$ \\ 1,2,3,4,5 Universitas Jember, Indonesia \\ (reni.fib@unej.ac.id)
}

\begin{abstract}
This is a Linguistic landscape (LL) study which discusses multilingualism as reflected for example in public signboards, names of goverment buildings, street names, advertising billboards, commersial shops in a certain territory. LL describes the relationsships between language, society, and place. This research explores how English is used in the expanding circle: tourism areas in Yogyakarta, Indonesia as manifested in the commercial bords. Although Bahasa Indonesia is the official language used, this does not mean that other languages will have a little share in the linguistic landscape. The total data used were 519 signboards which were analyzed qualitatively and quantitatively. This research found that in monolingual boards, the use of English was 23.7\%, and Indonesian was $73.5 \%$. The magnitude of the use of English, which is close to as salient as the use of Bahasa Indonesia, is particularly shown on the bilingual and multilingual signboards. This study highlights discussion on the representation of power of English in the investigated signboards, which was shown from the number of appearance and combination of English and other languages in the signboards. It is revealed that English is expressed not only for informative reasons but also for symbolic reasons such as indexing sophistication, cosmopolitanism, and fashionable appearance.
\end{abstract}

Keywords: commercial boards; English; linguistic landscape; power; visual grammar, Yogyakarta.

Linguistic landscape (LL) is a rapid growing field of study in sociolinguistics (Blommaert, 2013: 2). LL shows many about how languages are used and about the power certain languages exert over others, in other words signs are sociolinguistic evidence of the dynamic power existing between languages

DOI:http.

Available Online at jurnalunmuhjember.ac.id/index.php/ELLITE

ISSN (Print) : 2527-4120

ISSN (Online) : 2528-0066 and their speakers or users (Hopkyns \& van den Hoven, 2021). Landry and Bourhis (1997) construe LLs as reflecting ethnolinguistic vitality and directly reflecting the power and status of linguistic communities of speakers in a certain setting. The existence of signs for example, in the forms of advertising billboards, 
commercial shop signs, public signs on government buildings, street names, place names in public spheres, gives impressions of relative power a certain language group has. LL is an engaging academic inquiry which has attracted world-wide scholars in the field: Backhaus (2006) in Tokyo, Nikolaou (2016) in Athens, Greece, Shang \& Guo (2017) in Singapore, Alomoush (2019) in Jordan da Silva et al. (2021) in Indonesia to name a few. Various purposes of LL studies range from understanding the reasons behind the uses and language choices, ideologies, language varieties, and contestations of multiple forms of 'languages' as they are displayed in public spaces, including the discussion of power representation.

As sociolinguistic realities today are increasingly more diverse, multilingual, and global (Vertovec, 2007) due to globalization, more studies target on describing, explaining, exploring how multicultural and multilingual environments impact the visibility of several languages to compete in order to appear in the public space. Tourism has been one of causes of multilingualism as interactions among different language communities are manifested through contacts. Yogyakarta, a special region in Java island, Indonesia is located in the central part of the island. The majority of the people speak Javanese, a local language or which is usually named bahasa daerah, and national language Bahasa Indonesia. The discussion on the use of LL to understand the power representation of English in Yogyakarta, Indonesian context of tourism can provide insights into the wide spread of English as a lingua franca of the world (Jenkins, 2015) even in Asia region (Bolton \& Bacon-Shone, 2020) where 817 millions are speakers of English.

\section{Linguistic landscape and the representation of power}

Linguistic landscape (henceforth LL) focuses on the visibility and salience of language(s) on public signs in each territory (Landry \& Bourhis, 1997). It is contented that
LL in a particular territory does not only mark the language community geographically, but more importantly LL reveals the symbolic constructions of the space (Ben-Rafael et al., 2006); (Landry \& Bourhis, 1997). This is to say that the dominating presence of certain language(s) or otherwise shows very important social realities about the demography inhibiting the area. Nowadays, where the bigger portion of the world is constituted with the demography of multilingual and multicultural background, the linguistic landscape study becomes more important as it indexes the social realities resulting from the interactions of the diverse members of the group. Khazanah \& Kusumaningputri (2021) confirm that using the lens of LL the perceptions, negotiations, and contestations of languages within multilingual and multicultural language community are possible to be revealed. Conclusively, the predominant language in LL reflects the more strength or vitality that language's group establish over the other languages' speakers within the intergroup setting (Landry and Bourhis, 1997). Provided by such situation, in multilingual society the dominating language in public space is deemed more valuable and is more positively entitled for public affairs such as for economy activities. The predominance of a certain language, however, does not always index the ethnolinguistic vitality (Leeman \& Modan, 2009). The language that is deemed more valuable does not mean the bigger composition of its speakers in the demography. It is possible for one prestigious and powerful language to be dominating the LL panorama, but passively spoken by the members of the community. Such value might, for example, source from the perception of prestige held by community members to a language that is named as the lingua franca. Ben-Rafael, Shohamy, Amara, \& Trumper-Hecht (2006) maintain that the dominating language in LL construct certain symbols for the space not of its speakers.

The degree of salience and visibility of certain language over the others is used as 
a parameter to measure the extent of power that a certain language has in a public space. Sciriha (2002) clarifies that the measurement of the two are made possible in two ways: (1) through the quantification of the number of appearances of each language, and (2) through the profile of the language(s) dominance. The quantification requires the statistical procedure to obtain the rate of the dominance of each language coexisting in the area. The profile of the language dominance is described through the placement of the language on the signs. The examination of how it is written and placed on monolingual and, more noticeably, bilingual and multilingual signs gives clear visualization of the magnitude of its vitality in the landscape.

\section{Visual grammar analysis framework}

Images, in any forms, i.e. shopfront signages are compositions with which readers can decipher their meanings. For the compositions to be well received by its readers, the representation and interaction of elements involved are structured through 3 principles: 1) salience; 2) framing; 3) informational values (Kress, Gunther and Van Leeuwen, 2006). Salience focuses on how particular elements are projected out among the discernable syntagms for instance space where each element lies. It contributes on how the meanings are represented and how the linkage of the composed elements is established. Thus, spatial relation - center, margin, left and right, top and bottom - indicate different measures of salience. Center is the nucleus of information for which becomes the locus of attention (Kress, Gunther and Van Leeuwen, 2006; O'Halloran, 2004). From this, an image or text is more salient than the others presented on the board. Salience can be achieved in many other ways such as colour-contrasts, sharpness of focus, size, and for written texts, the use of capital versus lower case letters, font type, and style (Kress, Gunther and Van Leeuwen, 2006; Nikolaou, 2016). Second principle is framing. Referring to Kress and Leeuwen (2006), it is a defining line or border that distinguishes the images or texts whether they are more salient or less. Finally is the placement of elements of texts or images. They explain that an image or a text is divided through space placement that is left-right, upper-lower, and centre-margin. These three dimensional information system is meant as given-new, ideal-real, and central-margin. This is to say that an image or text which is placed on the left of the centre is the given element or an element that is assumingly familiar for its reader. Meanwhile, an image or a text on the right is namely new element signifying that something is not known or new to the readers. Similarly elements which take place at the upper section is considered as something ideal or the core of the information, whereas the lower section displays more "down-to-earth" information. Last, elements taking position at the centre of the composition are regarded as the "nucleus" of the information whereas those on the margins are "ancillary" and dependent elements (2006, p. 196).

\section{English on public signs}

English today is the most used global lingua franca with the estimate of 1.35 billion speakers in 2021 (O'Halloran, 2004) with the English as second language speakers far outnumber the native speakers. What this number suggests is the almost omnipotent existence of English in the countries stretching throughout the globe especially on the shop signs as economy is one of the main drives for globalization. Studies about English in outer and expanding circle countries reveal how English is positioned and perceived about its value in these countries. In an instance of English in the LL of outer circle countries, Álvarez-Mosquera \& Coetzee (2017) found that English was predominantly used on shop signs in a market in South Africa because it accentuated the local and global prestige; it also became the more opted written lingua franca due to the inadequate medium of instruction of South African indigenous languages in its education system. Another instance in 
this circle was reported by Tang (2018) who investigated the shape of the LL through the calculation of the four official languages and their compositions appearing on public signs found in 30 Singaporean Mass Rapid Transport. From his findings, Tang claimed that although Singapore is reputable for its multicultural and multilingual background, it certainly channeled English imperialism and that it is more of monolingual rather than multilingual oriented with English functioning as interethnic lingua franca. The reports about LL in expanding circle countries find different rates of vitality of English. Kasanga (2012) reported that English became the second most used language in the LL of one commercial district in Phnom Penh Cambodia; it was more favored than its colonial vestige language, French, and other coexisting languages; Japanese, Korean, and Chinese. Though English speakers might not predominantly occupy the area, it is the positive stereotypes that promote the value for the members of the community. English is seen as the language of modernity and even ensures superior qualities for the products advertised. In Indonesia itself, two research reports have been made about the LL in different tourism areas. In Indonesia, very few LL study has been conducted. Khazanah \& Kusumaningputri (2021), for example, found that English has a total domination in the commercial signboards in the LL of some tourism areas in Bali. In this research sites, it was found that English is the chosen lingua franca although speakers of other languages such as Chinese were equally big in number. This accentuated the use of English to construct certain symbolisms for the benefits of the business owners as in constructing 'up to date' and 'cosmopolitan' impressions for its readers. Da Silva et al. (2021) examined the LL of both government and commercial signs in Malioboro, Yogyakarta, reporting that Bahasa Indonesia was the one dominating the LL panorama due its rooted compliance to the national language policy and its consideration of Indonesian as the main target of readership. The very few studies reported in the area of
LL in Indonesia motivate this study to fill this gap.

\section{Method}

This article reported the selections of languages, the linguistic compositions of signboards, and the position of English in relation to power representation. This study employed an explanatory sequential mixed methods design (Creswell \& Creswell, 2018) to make sense for the frequency of appearance of English in LL in regard with power dimension of English as a lingua franca. The purpose of this study is to illustrate the representation of power of English as a lingua franca as displayed on the structures of the signboards. The research questions guiding this study are the following:

a. To what extent is the power of English represented on the signboards regarding its frequency of appearances?

b. How did the composition of the signboards contribute to the power representation of English in these places?

c. What possible motivations drive such extent of power?

\section{Data collection}

The research was carried out in some popular tourism areas in Yogyakarta namely Gunung Kidul, Gunung Api Purba Nglanggeran, Malioboro, Sleman, Beringharjo, Monumen Tugu Jogja, Upside Down World Jogja and Gembira Loka. The sites were selected due to their multicultural and multilingual potentials for they were visited by domestic and international tourists. Two Yogyakarta-based data collectors were assigned to photograph the main signboards of the stores. Using friendly equipment, camera or a mobile phone camera, they took 519 photographs. To avoid similar photos of the signboards, each data collector was allocated a distinct area. Data were taken in September 2020 for around 3 weeks. They were asked to take notes on the address of the shops where they photographed the signboards. After 
the data were gathered, coding was assigned and validation processes were ensured to clarify the information and convince there was no duplication.

\section{Data analysis}

The extent of power in this study is interpreted through visual hierarchy where visual prominence of the language of the text becomes the central determiner (Nikolaou, 2016). To achieve this goal, first, the data were classified according to their business types, and the frequency of English appearances on the monolingual, bilingual, and multilingual signboards was calculated. This helps to interpret the salience of English compared to other languages coexisting in the areas. The extent of power was further explored through the description of the linguistic composition of the signboards. For this, we followed (Nikolaou, 2016) textual types: primary text (brand names) and secondary text (informational text including the price, offers, etc). From this, we see how English was placed on the boards; whether it was used as the main text or informational text. The prominence was also explained using the principle of salience proposed by Kress and Van Leeuwen (2006) where salience was accentuated through the placement of the text on the upper and central area of the signboards, the bigger size of the font, and the boldness of the text. By describing the placement and structure of the English text, we could measure the degree of salience of English which contribute to its representation of power on signboards. Finally, the motives driving such degree of power representation were explained using the profile of research sites' demography and language policy of the community found in relevant literature in the field.

\section{Results and Discussion Results}

A total of 26 business types were identified, 2 of which accounted for more than 50 percent of the sample (see table 1 for percentage distributions). Of the 519 commercial signboards they were all independent business with no retail chains or corporations. Of the 519 primary signs; 287 were monolingual, 205 were bilingual, and 27 were multilingual (see Table 2). Significantly, there were ten languages used; Bahasa Indonesia, English, Javanese, Arabic, Italian, Chinese, Sundanese, Japanese, Korean, Spanish, France, Malay, and Using.

Table 1. The most frequent business types

\begin{tabular}{lll}
\hline Business types & N & $\%$ \\
\hline Fashion & 167 & 32.17 \\
Café n Restaurant & 105 & 20.23 \\
Eatery & 81 & 15.6 \\
Guest House & 46 & 8.86 \\
Laboratory & 1 & 0.2 \\
House stuff and decoration & 9 & 1.7 \\
Gift and Toys shop & 1 & 0.9 \\
Drug store & 6 & 1.15 \\
Decorative Plant & 4 & 0.7 \\
Grocery & 3 & 0.6 \\
Book Store and Stationery & 6 & 1.15 \\
Barbershop & 5 & 0.9 \\
Souvenir & 27 & 5.2 \\
Laundry and Carwash & 3 & 0.6 \\
Massage and reflexology & 2 & 0.4 \\
Money changer & 3 & 0.6 \\
Optic & 3 & 0.6 \\
Pet Shop & 1 & 0.2 \\
Photo Studio & 3 & 0.6 \\
Plastic Store & 1 & 0.2 \\
Tobacco Store & 6 & 1.15 \\
Sport & 1 & 0.2 \\
Spa and Salon & 7 & 1.3 \\
Repair Shop & 7 & 1.3 \\
Training Courses & 5 & 0.9 \\
Tour and Travel & 319 & 100 \\
\hline & & \\
\hline
\end{tabular}


Salience as reflected in language distributions across the monolingual, bilingual and multilingual boards

The first goal of the study is to draw the profile of the salience of English among the other coexisting languages in the LL of some tourism areas in Yogyakarta through its frequency of appearances on the signboards. The examination of English appearances in each category of the signboards helped to delineate its degree of vitality.

Table 2. The frequency of languages appearances on monolingual, bilingual, and multilingual signboards

\begin{tabular}{lllllll}
\hline Languages & $\begin{array}{l}\text { Monolin- } \\
\text { gual Sign- } \\
\text { boards }\end{array}$ & \multicolumn{2}{l}{$\begin{array}{l}\text { Bilingual } \\
\text { Signboards }\end{array}$} & $\begin{array}{l}\text { Multi- } \\
\text { lingual } \\
\text { Signboards }\end{array}$ \\
\cline { 2 - 7 } & $\mathrm{N}$ & $\%$ & $\mathrm{~N}$ & $\%$ & $\mathrm{~N}$ & $\%$ \\
\hline $\begin{array}{l}\text { Bahasa Indo- } \\
\text { nesia }\end{array}$ & 213 & 73.5 & 189 & 46.6 & 23 & 29.1 \\
English & 69 & 23.7 & 152 & 37.5 & 21 & 26.5 \\
Javanese & 5 & 1.7 & 54 & 13.3 & 17 & 21.5 \\
Mandarin & 1 & 0.3 & 3 & 0.7 & 4 & 5.1 \\
French & 1 & 0.3 & 1 & 0.2 & 1 & 1.2 \\
Italian & 1 & 0.3 & 1 & 0.2 & 1 & 1.2 \\
Japanese & - & & 2 & 0.5 & 3 & 3.8 \\
Using & - & & 1 & 0.2 & - & \\
Arabic & - & & 2 & 0.5 & 4 & 5.1 \\
Sundanese & & & & & 2 & 2.5 \\
Korean & & & & & 1 & 1.2 \\
Spanish & & & & & 1 & 1.2 \\
Malay & & & & & 1 & 1.2 \\
\hline
\end{tabular}

Table 2 shows that Bahasa Indonesia has a very strong domination in the monolingual signboards, and although the rates are not as high, it is also the most frequent language to appear on the bilingual and multilingual boards. From this extremely high rate of visibility, it is inferred that Bahasa Indonesia as the national language is the more preferred language by the shop owners to address their demography. In this LL panorama, English is seen as the second important language to be present on the signboards after Bahasa Indonesia. Using the rating presented in the table 2, English is always found in the second position in all categories: monolingual, bilingual, and multilingual signboards. As reflected by the frequency of English appearance in monolingual signboard category, it is inferred that although English is not the most salient language in the areas, it has a more supreme value compared to Javanese as the local language and other foreign languages coexisting in these sites i.e., Mandarin and Arabic. In the category of bilingual signboards, we see a huge gap between the high presence of English with the lower rates of appearance of the Javanese language and other foreign languages at present. Reading from this trend, the combination of Bahasa Indonesia and English in the signboards is much more likely to happen compared to the combination of Bahasa Indonesia with Javanese and other foreign languages. This calculation also suggests that the combination of Javanese and English is also shown in the LL. These combination trends show that English is seen by the shop owners as the more preferred counterpart over the local language and the foreign languages; thus, after Bahasa Indonesia, English is a language that is deemed to have more values of importance that cannot be catered by other coexisting languages.

Table 3. The language composition of primary text in the signboards

\begin{tabular}{lll}
\hline Languages & $\mathrm{N}$ & $\%$ \\
\hline Bahasa Indonesia & 374 & 60.2 \\
English & 159 & 25.6 \\
Javanese & 69 & 11.1 \\
Sundanese & 1 & 0.2 \\
Japanese & 4 & 0.6 \\
Italian & 2 & 0.3 \\
Arabic & 3 & 0.5 \\
Korean & 1 & 0.2 \\
Spanish & 1 & 0.2 \\
Chinese & 7 & 1.1 \\
\hline
\end{tabular}


Table 3 shows the percentage of distribution of languages used in the primary text. The calculation of the primary text consisting of the name of the store and often the type of shop indicates that Bahasa Indonesia is the language that is more widely used. Bahasa Indonesia is found as much as $60 \%$ of all primary texts. In the second place is English as many as 26\%, and followed by Javanese, one of the local languages, at $11 \%$.

Table 4. The language composition of secondary text in the signboards

\begin{tabular}{lll}
\hline Languages & $\mathrm{N}$ & $\%$ \\
\hline Bahasa Indonesia & 318 & 65.7 \\
English & 135 & 27.9 \\
Javanese & 22 & 4.5 \\
Sundanese & 0 & 0 \\
Japanese & 0 & 0 \\
Italian & 0 & 0 \\
Arabic & 0 & 0 \\
Korean & 1 & 0.2 \\
Spanish & 0 & 0 \\
Chinese & 4 & 0.8 \\
French & 2 & 0.4 \\
Using & 1 & 0.2 \\
Malay & 1 & 0.2 \\
\hline
\end{tabular}

The composition of the secondary text in the signboards is shown in table 4 . The number of languages used in the secondary text which serves to provide information about products, special offers and opening hours is less than the languages appearing in the primary text, which are only 8 languages. Table 4 also shows that Bahasa Indonesia occupies the top position in the secondary texts' compositions which is $66 \%$ of the entire signboards. English is in the second place by $28 \%$. Similar to the trend shown in table 3 , Javanese and Chinese came in the third and fourth position in secondary texts composition as much as $5 \%$ and $1 \%$. Other languages contained in this text are Korean, French and two local languages, namely Banyuwangi and Malay.

Finally, we observed how the visual prominence was constructed by the shop owners by examining which languages appeared in upper/ center placement, had bigger font size and had more intensity on the boldness. We made use of visual grammar analysis in particular developed by Kress and van Leeuwen (2006).

Table 5. Languages salience as shown by the visual grammar of the signboards

\begin{tabular}{lllllll}
\hline Languages & \multicolumn{2}{l}{$\begin{array}{l}\text { Upper/ } \\
\text { Center }\end{array}$} & \multicolumn{2}{l}{ Bigger } & \multicolumn{2}{l}{ Bolder } \\
\cline { 2 - 7 } & $\mathrm{N}$ & $\%$ & $\mathrm{~N}$ & $\%$ & $\mathrm{~N}$ & $\%$ \\
\hline $\begin{array}{l}\text { Bahasa Indo- } \\
\text { nesia }\end{array}$ & 369 & 63.2 & 364 & 62.5 & 369 & 63.2 \\
English & 142 & 24.3 & 147 & 25.3 & 141 & 24.1 \\
Javanese & 57 & 9.8 & 55 & 9.5 & 58 & 9.9 \\
Sundanese & 1 & 0.2 & 1 & 0.2 & 1 & 0.2 \\
Japanese & 1 & 0.2 & 1 & 0.2 & 1 & 0.2 \\
Italian & 2 & 0.3 & 2 & 0.3 & 2 & 0.3 \\
Arabic & 3 & 0.5 & 3 & 0.5 & 3 & 0.5 \\
Korean & 1 & 0.2 & 1 & 0.2 & 1 & 0.2 \\
Spanish & 1 & 0.2 & 1 & 0.2 & 1 & 0.2 \\
Chinese & 6 & 1.0 & 6 & 1.0 & 6 & 1.0 \\
French & 1 & 0.2 & 1 & 0.2 & 1 & 0.2 \\
\hline & 584 & & 582 & & 584 & \\
\hline
\end{tabular}

Table 5 shows the language salience visible through the position of elements either in the upper or center of the signboards, as well as the bigger and bolder fonts they have. The trend shows that Bahasa Indonesia is the most frequently used language with around $60 \%$, and English becomes the second top used language after Bahasa at around 24\%. Javanese, as the vernacular language, is in the third position among the top appeared languages. Some other languages, from local to foreign languages, such as Sundanese, Arabic, Chinese, Korean, Japanese, Spanish, Italian, and French are reported to be used less than $2 \%$. These results suggest that Bahasa Indonesia is the most salient and English is the second most 
salient in the investigated signboards.

\section{Discussion}

English in the LL of tourism areas in Yogyakarta has vitality sufficiently high because it is the second most used language after Bahasa Indonesia. Additionally, English vitality is also manifested in the combination of languages in the signboard as it is consistently chosen as the counterpart of Bahasa Indonesia and Javanese. This choice reflects certain symbolism or values that try to be constructed by the shop owners. A study by da Silva et al. (2021) argue that Bahasa Indonesia domination in Malioboro, Yogyakarta was motivated by the rooted national language policy and the expected readership. This was backgrounded by the fact that Malioboro location was visited more by domestic tourists. On their discussion, they concluded Bahasa Indonesia serve both informative and symbolic functions. Reflecting from the findings of the current study, the findings share some similarity with da Silva et al. (2021). However, the highlight on the power of English regarding its appearance in the signboards also tells something interesting. We observed that English is frequently juxtaposed with Bahasa Indonesia in primary text. This suggests that the use of English reflects certain identity the shop owners want to project to the customers. Alomoush (2019) who studied LL shop fronts in Jordan revealed that cosmopolitanism and modern association leverage English salience in the shop fronts. The same conclusion was also asserted by Curtin (2014), Hopkyns \& van den Hoven (2021), Khazanah \& Kusumaningputri (2021), Lanza \& Woldemariam (2014), Manan et al., (2017).

In Figure 1, three languages namely English the and of, Bahasa Indonesia waroeng and Javanese Raminten are used to construct the brand name of a local restaurant in Yogyakarta. The incorporation of the and of on the name of this restaurant marks the cosmopolitanism as the name is intended to attract global audience.

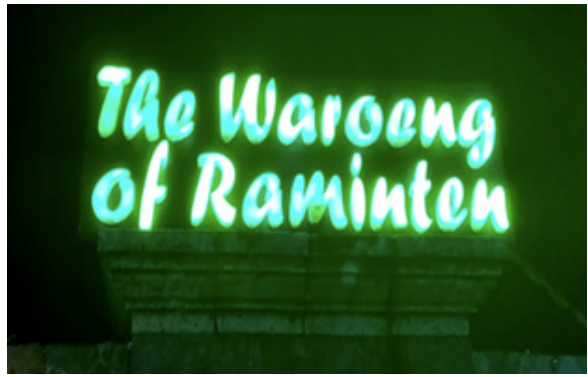

Figure 1. The combination of English, Bahasa Indonesia, and Javanese shown in primary text

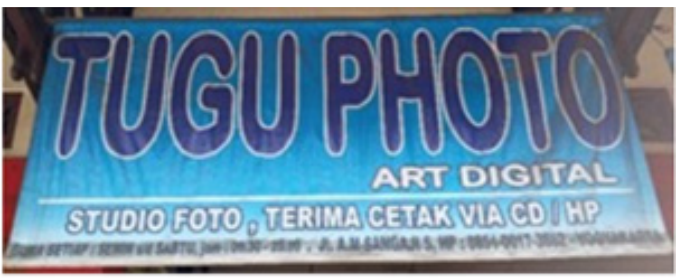

Figure 2. English and Bahasa Indonesia occupy upper/center, bigger size, and bolder language placement

In Figure 2, the word Tugu in Bahasa Indonesia is paired with the English word photo sharing identical big size almost taking the whole space of the signboard. The two words were placed in the upper part of the sign and were written in intensely bold manner. This shows that English placement is equally salient with Bahasa Indonesia word. In other word, this makes a case for power of English in the commercial signboards.

In Figure 3 and Figure 4, again the power of English is seen from this signboard by the collaboration between Bahasa Indonesia and English both in primary text and secondary text. Primary text describes the brand names and business types. This suggests that the shop owners index a certain identity that reflects the power of English as a lingua franca. Many local shops for instance fashion business types or other local business use catchy phrases, and many often the phrase are the combination of the two languages. Other examples are Irien salon, Saka Garden, Batik Roebini -The taste of Indonesia. From these choices Indonesians seem to adopt some English words that are very 


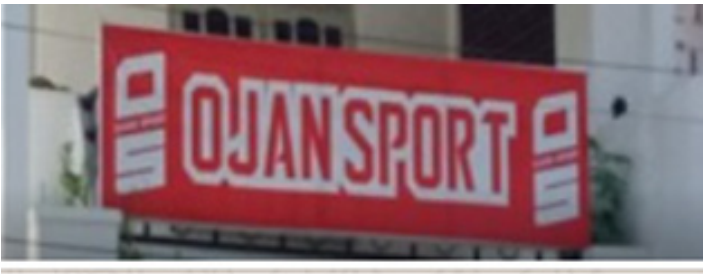

Figure 3. The use of English and Bahasa Indonesia in primary text

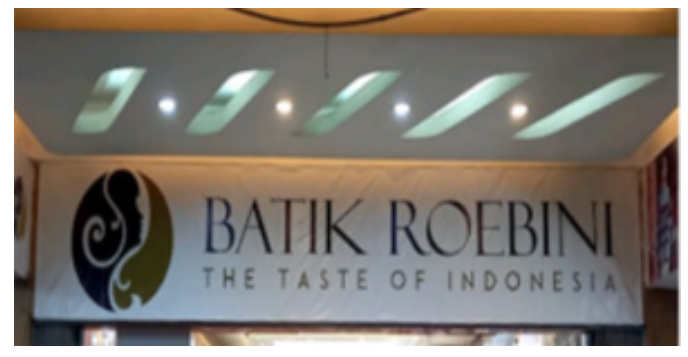

Figure 4. The use of English in secondary text

familiar in Indonesian society. Words such as accessories, fashion, exclusive, indoor, three in one, sport attract young buyers. These words not only indicate the enrichment of Indonesian lexis (Lauder, 2008; Lowenberg, 1991) in terms of providing more neutral as well as prestigious traits (Lowenberg, 1991), but also attract more young potential buyers. The interrelation between economy and the use of linguistic codes (Heller, 2003) explains the visibility and salience of English and Bahasa Indonesia, thus highlighting the power representation.

\section{Conclusion}

Using the calculation of the distribution of languages across the signboards, identification of the languages used in primary and secondary texts (Nikolaou, 2016) and visual prominence through visual grammar analysis (Kress and van Leeuwen, 2006), this study portrays the degree of power manifested in commercial signboards in the LL of several tourism areas in Yogyakarta. The three-fold stages visualize the salience that English has compared to other coexisting languages in the areas. English was found as the secondmost salient language in these commercial signboards after Bahasa Indonesia. Its power is represented by its big portion of distribution in monolingual, bilingual, and multilingual signs: its appearance is much more productive than Javanese as the local language and other foreign languages found in the sites. The examination of the distribution of languages in the primary and secondary text also informs that English is the second most productive language used in both categories. Moreover, the combination of languages found in the primary texts and secondary texts of the bilingual and multilingual boards has confirmed that English is the highly chosen counterpart of Bahasa Indonesia. English salience is also accentuated by its placement in the boards; after Bahasa Indonesia, many English words were located in the upper/center part of the boards and written in bigger and bolder fonts. This representation of power shows that English is more powerful than the local language and other foreign languages in the area. This confirms Lauder's (2008) claim of English position in Indonesia; it is the most important foreign language in this country. In this study, we discuss why English is important for the shop owners in the areas. It is found that although English is not mainly used to target readers' understanding of the information, it is used to create certain symbols desired by the shop owners, namely to mark 'modernism' and 'cosmopolitanism. To the researchers intending to pursue richer exploration of the LL study, we would recommend to provide different settings of LL panorama to complete the more holistic view of the position of English in the LL of Indonesia.

\section{Declaration}

No potential conflicts of interest with respect to the research, authorship, and publication of this article.

\section{References}

Álvarez-Mosquera, P., \& Coetzee, F. (2017). "It makes it legit": local semiotic perceptions of the linguistic landscape in a market 
in Soshanguve, South Africa. Social Semiotics, 28(4), 494-511. https://doi. org/10.1080/10350330.2017.1406569

Backhaus, P. (2006). Multilingualism in tokyo: A look into the linguistic landscape. International Journal of Multilingualism, 3(1), 52-66. https:// doi.org/10.1080/14790710608668385

Ben-Rafael, E., Shohamy, E., Amara, M. H., \& Trumper-Hecht, N. (2006). Linguistic landscape as symbolic construction of the public space: The case of Israel. Linguistic Landscape: A New Approach to Multilingualism, November 2012, 7-30.

Blommaert, J. (2013). Ethnography, Superdiversity and Linguistic Landscapes Chronicles of Complexity. Multilingual Matters. https://doi.org/10.1016/j. socscimed.2006.08.004

Bolton, K., \& Bacon-Shone, J. (2020). The Statistics of English across Asia. The Handbook of Asian Englishes, 49-80. https://doi.org/10.1002/9781118791882. ch3

Creswell, W. John \& Creswell, J. D. (2018). Research Design: Qualitative, Quantitative and Mixed Methods Approaches. In Journal of Chemical Information and Modeling (Vol. 53, Issue 9).

Curtin, M. (2014). Mapping cosmopolitanisms in Taipei: Toward a theorisation of cosmopolitanism in linguistic landscape research. International Journal of the Sociology of Language, 228, 153-177. https://doi.org/10.1515/ijsl-2014-0009

Da Silva, A. M., Tjung, Y. N., Wijayanti, S. H., \& Suwartono, C. (2021). Language use and tourism in Yogyakarta: The linguistic landscape of Malioboro. Wacana, 22(2), 295-318. https://doi.org/10.17510/ WACANA.V22I2.721

Heller, M. (2003). Globalization, the new economy, and the commodification of language and identity. Journal of Sociolinguistics, 7(4), 473-492. https://doi.org/10.1111/j.14679841.2003.00238.x

Hopkyns, S., \& van den Hoven, M. (2021). Linguistic diversity and inclusion in $\mathrm{Abu}$ Dhabi's linguistic landscape during the COVID-19 period. Multilingua. https:// doi.org/10.1515/multi-2020-0187

Jenkins, J. (2015). Global Englishes (third). Routledge.

Kasanga, L. A. (2012). Mapping the linguistic landscape of a commercial neighbourhood in Central Phnom Penh. Journal of Multilingual and Multicultural Development, 33(6), 553-567. https:// doi.org/10.1080/01434632.2012.683529

Khazanah, D., \& Kusumaningputri, R. (2021). Unpacking Multilingualism in Tourism Peripheries in Bali: Taking a Look into Private Shop-fronts. K@Ta, 23(1),28-37. https://doi.org/10.9744/kata.23.1.28-37

Kress, Gunther and Van Leeuwen, T. (2006). Reading Images The Grammar of Visual Design (Second Ed.). Routledge.

Landry, R., \& Bourhis, R. Y. (1997). Linguistic landscape and ethnolinguistic vitality: An empirical study. Journal of Language and Social Psychology, 16(1), 23-49. https:// doi.org/10.1177/0261927X970161002

Lanza, E., \& Woldemariam, H. (2014). Indexing modernity: English and branding in the linguistic landscape of Addis Ababa. International Journal of Bilingualism, 18(5), 491-506. https://doi. org/10.1177/1367006913484204

Lauder, A. (2008). The Status and Function of English in Indonesia: a Review of Key Factors. Makara Human Behavior Studies in Asia, 12(1), 9. https://doi. org/10.7454/mssh.v12i1.128

Leeman, J., \& Modan, G. (2009). Commodified language in Chinatown: A contextualized 
approach to linguistic landscape. Journal of Sociolinguistics, 13(3), 332362. https://doi.org/10.1111/j.14679841.2009.00409.x

Lowenberg, P. H. (1991). English as an additional language in Indonesia. World Englishes, 10(2), 127-138. https:// doi.org/10.1111/j.1467-971X.1991. tb00146.x

Manan, S. A., David, M. K., Dumanig, F. P., \& Channa, L. A. (2017). The glocalization of English in the Pakistan linguistic landscape. World Englishes, 36(4), 645665. https://doi.org/10.1111/weng.12213

Nikolaou, A. (2016). Mapping the linguistic landscape of Athens: the case of shop signs. International Journal of Multilingualism, 14(2), 160-182. https:// doi.org/10.1080/14790718.2016.1159209

O'Halloran, K. L. (2004). Multimodal Discourse Analysis Systemic-Functional Perspectives. Continuum.

Salameh Alomoush, O. I. (2019). English in the linguistic landscape of a northern Jordanian city. English Today, 35(3), 35-41. https://doi.org/10.1017/ S0266078418000391

Sciriha, L. (2002). The Rise of Maltese in Malta: Social and Educational Perspectives. New Perspectives of Languages and Teaching, 95-106.

Shang, G., \& Guo, L. (2017). Linguistic landscape in Singapore: what shop names reveal about Singapore's multilingualism. International Journal of Multilingualism, 14(2), 183-201. https://doi.org/10.1080 /14790718.2016.1218497

Tang, H. K. (2018). Linguistic landscaping in Singapore: multilingualism or the dominance of English and its dual identity in the local linguistic ecology? International Journal of Multilingualism, 17(2), 152-173. https://doi.org/10.1080 /14790718.2018.1467422
Vertovec, S. (2007). Super-diversity and its implications. Ethnic and Racial Studies, 30(6), 1024-1054. https://doi. org/10.1080/01419870701599465 